\section{AINA NEWS}

\section{KLRS Receives Major Grants}

There has been some good news for Kluane Lake Research Station (KLRS) this spring, as two large research grants have come through in support of station operation, maintenance, and scientific initiatives. NSERC partially resurrected their major facilities research program this year, through two-year Operations and Maintenance Support grants. AINA received an award of $\$ 148200$ per year in support of KLRS for the years 2017-19, thanks to the collective effort of a strong team of co-investigators who represent the exceptional, long-term research efforts based at KLRS.

A second grant has recently been awarded from Polar Knowledge Canada in support of cryosphere-climate monitoring at Kluane Lake Research Station. This award totals \$249 500 over two years, 2017-19, with funds divided between AINA, Yukon College/Yukon Research Centre, the University of Ottawa, and Simon Fraser University. This grant will provide the base funding for the implementation of KLRS as an official Cryonet site within the World Meteorological Organization (WMO) Global Cryosphere Watch (GCW). As a GCW site, the KLRS-based meteorological station will be upgraded: we are adding a WMO-calibre rain gauge at the station and initiating long-term cryospheric monitoring of local snow and lake ice conditions and the regional permafrost and glacier mass balance. In support of the latter two objectives, an altitudinal transect of meteorological stations is planned for the Kaskawulsh Valley, which will build on existing monitoring infrastructure and research programs operating at this site. This monitoring will be an exciting addition to the range of research programs operating out of KLRS over the coming years.

\section{Scholarship Winners}

Michael Peers, a doctoral candidate in the Department of Biological Sciences at the University of Alberta, is the 2017 recipient of the Jennifer Robinson Memorial Scholarship. For his doctoral research, Michael is investigating the potential vulnerability of snowshoe hares to climate change as their seasonal moults to a white or brown coat become increasingly mismatched with the presence or absence of snow cover, thereby making them more vulnerable to predators. Using a combination of radio telemetry, trail cameras, trapping, and GPS technology, Michael will monitor the survival of snowshoe hares near Kluane Lake, Yukon.

The 2017 recipient of the Lorraine Allison Scholarship is Ellorie McKnight, who is also a doctoral student in the Department of Biological Sciences, University of Alberta. Ellorie is conducting limnological research at Kluane Lake, Yukon, to assess the impact of climate changes on the water properties of the lake and how changing thermal dynamics in the lake could affect the habitat and survivability of aquatic species such as lake trout.
Special thanks to the members of the two scholarship committees for their time and effort in assessing the applications. Applications to the Jennifer Robinson Memorial Scholarship were vetted by Geoff Scudder, John Krebs, Mary Vetter, Ryan Danby, and Maribeth Murray. The members of the 2017 Lorraine Allison Scholarship Committee were Dee McRae, Bill Elton, Heather Myers, Everett Peterson, Janet Wright, and Maribeth Murray. AINA Administrative Assistant Melanie Paulson coordinated the work of both committees.

\section{Grant-in-Aid Recipients}

This year the selection committee received 16 applications for grants-in-aid and awarded grants for 2017 to eight successful applicants.

Kelsey Nyland, Michigan State University, is studying the role of nivation in cryoplanation terraces in the Beringian uplands of central Alaska; Jason Miszaniec, University of California, Davis, is investigating fishing economies in Norton Sound, Alaska; Andrew Barnas, University of North Dakota, is quantifying long-term changes in the summer diets of polar bears in western Hudson Bay; Adam Eichenwald, Yale University, New Haven, Connecticut, is studying the effects on grouse behavior of predation by gyrfalcons in Alaska; Joanna Wells, University of Alaska, Anchorage, is researching Dena'ina food storage and subsistence at Cottonwood Creek Village in Southcentral Alaska; Emile BrissonCuradeau, McGill University, Montreal, is investigating the use of the Thick-billed Murre as an indicator of climate change; Becky Segal, University of Victoria, is integrating remote sensing and traditional ecological knowledge to identify historical and current hazards in sea ice travel in Cambridge Bay, Nunavut; and Scott Zolkos, University of Alberta, Edmonton, is investigating the processing and release of inorganic carbon in streams across a rapidly thawing permafrost landscape in the Northwest Territories.

The members of the Grant-in-Aid Selection Committee for 2017 were Alexander Braun, Tom Dunning Newbury, Mary Stapleton, Matthew Sturm, and Brent Else. Proposals for 2018 are due on 1 February. Please refer to the AINA website for application information.

\section{Researching the Arctic Whaling Trade}

AINA post-doctoral fellow Matthew Ayre conducted two research trips, to the United Kingdom in March and the United States in April, to identify and digitally photograph logbooks surviving from the Arctic whaling trade. During the UK trip, Ayre visited seven archives and photographed 53 Arctic whaling logbooks of vessels that undertook voyages to Davis Strait and Baffin Bay to hunt bowhead whales. British voyages to the Davis Strait whale fishery lasted approximately seven months (April-October). On a shorter trip to New Bedford, Massachusetts, and Mystic, Connecticut, he photographed an additional 49 logbooks. 
These included a small number of British logbooks, but the bulk were logbooks from the short-lived American bowhead fishery in Hudson's Bay. Those voyages lasted two years on average and typically overwintered in the bay. Collectively, this set of 102 logbooks covers the early 19th to early 20th century and will yield over 42000 new daily observations of wind, weather, and sea ice to improve our understanding of the climate in this region. Digital copies of all the logbooks imaged have been sent to host archives for their records.

\section{CCADI: The Canadian Consortium for Arctic Data Interoperability}

The Canadian Consortium for Arctic Data Interoperability is a group of Canada's foremost Arctic scholars and Arctic data managers from the University of Calgary (the Arctic Institute of North America and the GeoSensorWeb Lab), Carleton University (the Geomatics and Cartographic Research Centre), Université Laval (Centre d'études nordiques), the University of Manitoba (Centre for Earth Observation Science), the University of Ottawa (Faculty of Law), the University of Waterloo (Canadian Cryospheric Information Network and Polar Data Catalogue), Inuit Tapiriit Kanatami, the Inuvialuit Regional Corporation, Natural Resources Canada, Polar Knowledge Canada, Cybera Inc., Polar View, and SensorUp Inc.

The CCADI purpose is to advance national and international collaboration by developing an integrated Canadian Arctic data management system that facilitates information discovery, establishes metadata and data sharing standards, enables interoperability among existing data infrastructures, and is accessible to the broadest possible audience of users, particularly to users in Canada's North.

The Arctic Institute of North America is proud to be a founding member of this initiative. More information about the CCADI can be found online at www.ccadi.ca.

\section{More Research Project Descriptions in ASTIS}

The Arctic Institute of North America's Arctic Science and Technology Information System (ASTIS), now contains more than 83000 records, 18000 of which are research project descriptions from Yukon, the Northwest Territories, and Nunavut, which are derived from information collected by agencies that license field research.

Research projects often involve both fieldwork and data collection that require permission from organizations licensing research for specific regions. These licenses or permits are typically issued to a researcher or to an organization for a specific period of time; projects that extend over a period of more than one year may require more than one license. Research project descriptions collected in the ASTIS database can help people find information on research conducted in specific areas of the Canadian Arctic, including their own communities. This information can also help researchers find projects similar to their own planned work or to learn about research projects being conducted in the same area, which creates opportunities for collaboration and limits duplication of logistics or data collection.

The ASTIS database is available for free online at http:// www.aina.ucalgary.ca/astis/. Users can limit their search to research projects by selecting "Research Projects Only" from the Record Type drop-down menu. 